\title{
Fatty Acid Profiles of Fin Fish in Langkawi Island, Malaysia
}

\author{
Farida Osman ${ }^{1}$, Irwandi Jaswir ${ }^{1,2 *}$, Huzwah Khaza'ai ${ }^{1}$ and Ridzwan Hashim ${ }^{3}$ \\ ${ }^{1}$ Department of Biotechnology, Faculty of Science, International Islamic University Malaysia (Jalan Gombak, 53100 Kuala Lumpur, MALAYSIA) \\ ${ }^{2}$ Lipid Laboratory, Food Research Division, National Food Research Institute (2-1-12 Kannondai, Tsukuba, Ibaraki, 305-8642 JAPAN) \\ ${ }^{3}$ Department of Biomedical Science, Faculty of Science, International Islamic University Malaysia (Jalan Gombak, 53100 Kuala Lumpur, MALAYSIA)
}

\begin{abstract}
Total lipid contents and fatty acid composition of 13 marine fish species namely, "jenahak" (Lutianus agentimaculatus), "kebasi" (Anadontostoma chacunda), "duri”" (Arius cumatranus), "tenggiri batang" (Scomberomorus commersoni), "kembong" (Rastrelliger kanagurta), "kintan" or "sebalah" (Psettodes crumei), "kerisi" (Pristipomodes typus), "kerapu" (Epinephelus sexfasciatus), "gelama kling" (Sciaena dussumieri), “malong" (Congresax talabon), "laban" (Cynoglossus lingua), "yu 9" (Scolidon sorrakowah) and "bagi" (Aacnthurs nigrosis) commonly found in Pulau Tuba, one of the islands surrounding the popular tourist destination Langkawi in Malaysia were determined. All fish showed a considerable amount of unsaturated fatty acids particularly those with 4, 5 and 6 double bonds. Two physiologically important n-3 polyunsaturated fatty acids (PUFAs), i.e. eicosapentaenoic acid (EPA) and docasahaexaenoic acid (DHA), made up of more than 50\% of the total PUFAs. For saturated fatty acids, palmitic was found to be the major one in all types of fish studied. Based on DHA, EPA and arachidonic acid (AA) contents, "gelama kling" was found to be the best source $(23,11$ and $7 \%$, respectively) followed by "kerapu" $(21,10,9 \%)$ and "sebalah" $(19,14,4 \%)$.
\end{abstract}

Key words: fatty acid profile, EPA, DHA

\section{INTRODUCTION}

Fatty acids of fish oil have considerable distinguished characters compared to fatty acids from other sources (Shahidi, 1998). Fish lipids and fatty acids composition stem from observation of the diet of Greenland Eskimos whom were observed to have lower incidence of cardiovascular diseases Currently, it is known that fatty acids of fish flesh are the most beneficial for human health due to its high proportion of unsaturated fatty acid. Fish lipids are well known to be rich in long chain n-3 polyunsaturated fatty acid (PUFA), especially eicosapentaenoic acid (EPA) and docosahexaenoic acid (DHA). These fatty acids play a vital role in human nutrition, disease prevention, and health promotion. Above and beyond that, humans can not synthesis n-3 fatty acids and must be provided through diet. (Bang et al., 1976).

The clinical trials show that consumption of long chain n-3 PUFA reduces the risk of coronary heart diseases, lower the incidence of mild hypertension and diabetes, and prevent cardiac arrhythmias and sudden death (Skonberg and Perkins, 2005; Leaf and Weber, 1988; Conner, 1997). Long chain n-3 PUFAs are known to be essential in neural development in the infant in utero and during the first few years after birth (Çelik et al., 2005; Alasalvar et al., 2002). They are also found to have beneficial effects in inflammation, arrhythmias, psoriasis, aggression, depression, inflammatory and auto-immune disorders and cancer (Haliloğlu et al., 2004). Considering all these nutritional and health implication, it is hard to neglect the importance of eating fish which are rich in long chain n-3 PUFAs.

Current research indicated that fatty acid composition of the fish differs due to climatic condition, diet, age, maturity and type of species (Haliloğlu, 2004; Çelik et al., 2005; Ratkowsky, 1996; Kinsella, 1988; Saito et al., 1999). Fish from tropical climate were found to have lesser amount of total lipids compared to those from arctic region. Besides, the lipids of fresh water feeds are characterized by linoleic $(\mathrm{C} 18: 2 \mathrm{n}-6)$ and linolenic (C18:3 n-3) acids and EPA (Haliloğlu, 2004; Çelik et al., 2005). While, the plankton of marine feeds present low levels on n-6 PUFA, of which EPA

\footnotetext{
* Correspondence to: Irwandi Jaswir, Lipid Laboratory, Food Research Division, National Food Research, Institute, 2-1-12 Kannondai, Tsukuba, Ibaraki, 305-8642 JAPAN

E-mail: irwandi@affrc. go. jp
}

Accepted November 3, 2006 (received for review August 10, 2006)

Journal of Oleo Science ISSN 1345-8957 print / ISSN 1347-3352 online

http://jos.jstage.jst.go.jp/en/ 


\section{F. Osman, I. Jaswir, H. Khaza'ai et al.}

and DHA are the predominant acids (Justi et al., 2003). Thus, marine fish are distinguished with high concentration of $\mathrm{n}-3$ since they feed on planktons while fresh water fish mainly constitute $\mathrm{n}-6$ fatty acids.

This study was conducted to determine fatty acid profiles of wild marine fin fish caught in Pulau Tuba area, near the popular tourist destination Langkawi Island, Malaysia.

\section{MATERIALS AND EXPERIMENTAL DESIGN}

\subsection{Material}

Wild marine fin fish caught from Pulau Tuba area, near Langkawi Island, on 15 October 2004 were used as the samples of this study. The samples were washed with clean sea water at the point of collection, separated by species, packed in plastic bags and transferred to the laboratory under ice boxed where they were kept at $-27^{\circ} \mathrm{C}$ until analyzed. The entire reagents used during the analysis were of analytical grade. Menhaden oil (Sigma Chem. Co.) was used as standard PUFA.

\subsection{Experimental design}

Thirteen species commonly found in the study area were analyzed. The names, number and average weight and size of species analyzed are presented in Table 1.

Prior to extraction of the oil the fish was thawed at $4^{\circ} \mathrm{C}$ for 12 hours and duplicated samples of each type of fish as shown in Table 1 were obtained from eviscerated fish consisting of flesh and skin. The fish lipids were extracted by Folch (1957) method with slight modifications. The fish samples were divided into three parts: head, stomach and tail. Representative samples from each part were homogenized with a mixture of chloroform and methanol $(2: 1, \mathrm{v} / \mathrm{v})$. Sodium chloride solution $(0.9 \%, \mathrm{NaCl})$ were added to the homogenate and centrifuged at $3000 \mathrm{rpm}$ for $15 \mathrm{~min}$ at $4^{\circ} \mathrm{C}$ after vortex three times for 30 seconds. The lower clear phase were collected and concentrated with a rotary evaporator at $35^{\circ} \mathrm{C}$. The concentrated lipid extract was quantitatively transferred to a vial. Aliquots were evaporated to constant weight under nitrogen to determine total lipid content.

\subsection{Fatty acid analysis}

Fatty acids contents of the total lipid extracted were determined by methlylation of $0.1 \mathrm{~g}$ of lipid with $1 \%$ sulphuric acid-methanol at $95^{\circ} \mathrm{C}$ for $2 \mathrm{~h}$. The lipid samples were placed in a test tube then $1 \mathrm{~mL}$ of toluene and $1 \mathrm{~mL}$ of the sulphuric acid-methanol were added and the mixtures were heated for $2 \mathrm{~h}$ at $95^{\circ} \mathrm{C}$. After cooling the samples under ice, $1 \mathrm{~mL}$ of water and hexane were added and the samples were vortexed and centrifuged. The methylated fatty acids were collected under hexane and evaporated by nitrogen gas and then reconstitute with hexane before running for gas chromatography (GC) for fatty acid analysis.

\subsection{Gas-chromatography analysis}

Routine analyses of fatty acid methyl esters (FAMEs) were performed by a Perkin Elmer gas cromatographymass spectrometer (GC-MS) Model Autosystem XL equipped with FID detector where hydrogen and compressed air were used. A capillary column $\left(30 \mathrm{~m} \times\right.$ diame- $^{-}$

Table 1 Names, Number, Size and Weight of Wild Marine Fin Fish Analyzed.

\begin{tabular}{|c|c|c|c|c|c|}
\hline Local Name & Common Name & Scientific Name & $\begin{array}{c}\text { No. of } \\
\text { fish } \\
\text { analyzed }\end{array}$ & $\begin{array}{c}\text { Average } \\
\text { Weight (g) }\end{array}$ & $\begin{array}{c}\text { Average } \\
\text { Size }(\mathrm{cm})\end{array}$ \\
\hline "Duri" & Marine catfishes & Lutianus agentimaculatus & 7 & $799.92 \pm 23.53$ & $38 \pm 5$ \\
\hline "Kintan" & Pseudo rhombus & Arius cumatranus & 7 & $36.09 \pm 5.22$ & $15 \pm 4$ \\
\hline "Jenahak" & Golden snapper & Epinephelus sexfasciatus & 6 & $148.13 \pm 18.40$ & $20 \pm 4$ \\
\hline "Kerisi” & Threadfin breams & Scomberomorus commersoni & 5 & $79.16 \pm 9.23$ & $21 \pm 3$ \\
\hline "Gelama kling" & Drum-croaker-jewfish & Pristipomodes typus & 5 & $83.72 \pm 8.45$ & $15 \pm 2$ \\
\hline "Laban" & Tongue soles & Congresax talabon & 5 & $110.10 \pm 12.65$ & $15 \pm 3$ \\
\hline “Malong” & Pike and conger eels & Rastrelliger kanagurta & 4 & $105.52 \pm 11.88$ & $20 \pm 5$ \\
\hline "Kembong" & Indian mackerels & Psettodes crumei & 4 & $670.80 \pm 22.80$ & $32 \pm 5$ \\
\hline "Tinggiri batang" & Spanish mackerels & Scolidon sorrakowah & 3 & $144.64 \pm 12.75$ & $30 \pm 6$ \\
\hline “Kerapu” & Groupers & Cynoglossus lingua & 2 & $449.54 \pm 26.11$ & $70 \pm 6$ \\
\hline "Kebasi" & Anodontostoma & Aacnthurs nigrosis & 2 & $321.53 \pm 15.40$ & $30 \pm 4$ \\
\hline “Yu 9” & Lizardfishes & Anadontostoma chacunda & 1 & $132.68 \pm 13.80$ & $37 \pm 4$ \\
\hline \multirow[t]{2}{*}{ "Bagi" } & Aacnthurs nigrosis & Sciaena dussumieri & 1 & $270.54 \pm 6.54$ & $32 \pm 3$ \\
\hline & & & Total: 52 & & \\
\hline
\end{tabular}


ter $0.25 \mu \mathrm{m}$ film thickness) with split ratio of $50: 1$ was used to separate the esters. Hexane was used as a liquid phase for the sample. The analyses were performed at initial temperature of $160^{\circ} \mathrm{C}$ for 5 minutes and raised to $250^{\circ} \mathrm{C}$ for 10 min at a rate of $4^{\circ} \mathrm{C} / \mathrm{min}$. Temperature of injector and detector was $280^{\circ} \mathrm{C}$. Helium gas was used as carrier gas flowing at $1 \mathrm{~mL} / \mathrm{min}$. The fatty acids compositions of the sample and fish oil were identified by comparison with retention times of known standard mixture (Sigma Chem. Co.) of fatty acids. Menhaden oil (Sigma Chem. Co.) was used as standard PUFA.

\section{RESULTS AND DISCUSSION}

\subsection{Lipid contents of fin fish in Pulau Tuba}

The lipid contents of the different parts of fish studied are presented in Table 2. The lipid analysis was conducted for head, middle and tail parts of the fish. In general, it was found that "kintan" (Psettodes crumei) was the species with the highest lipid contents. It has $21.5 \%$ lipid in head, 13.8\% (middle) and 14.4\% (tail). "Duri” (Arius cumatranus) came second with 20.3, 13.6 and $14.2 \%$ for its head, middle and tail.

Fish are often classified on the basis of their fat content into lean fish, medium fat fish and fatty fish (Suriah et al., 1995). Fish are termed as lean fish when total lipid is below $5 \%$ and fatty fish when the fat content is more than $10 \%$. While medium fat fish have $5-10 \%$ fat by weight. Based on this classification, "kintan" (Psettodes crumei) and "duri" (Arius cumatranus) were classified as fatty fish, as the fat concentration in each part of the body was more than $10 \%$. When looking at the head composition, "jenahak" (Lutianus agentimaculatus) could be also classified to that group. This species was also fatty in tail, but lean in the middle part. Four types of fish in this study, namely "kerisi" (Pristipomodes typus), "gelama kling" (Sciaena dussumieri), "kembong" (Rastrelliger kanagurta) and "kebasi" (Anadontostoma chacunda) were found to be medium fat fish according to their head lipid contents, while the others were lean.

For the middle parts of the fish body, "kerisi" (Pristipomodes typus) and "kembong" (Rastrelliger kanagurta) were also under the category of fatty fish. Two others; "malong" (Congresax talabon) and "jenahak" (Lutianus agentimaculatus) were medium fat, while the rest were lean.

Different from the head and middle parts, for the tail lipid content, many of the fish studied were fatty. Apart from "duri" (Arius cumatranus) and "kintan" (Psettodes crumei), four other types of fish were also considered fatty fish. They were "jenahak" (Lutianus agentimaculatus) (12.13\%), "kerisi" (Pristipomodes typus) (10.45\%), "gelama kling" (Sciaena dussumieri) (14.06\%), and "laban" (Cynoglossus lingua) (14.06\%). "Malong" (Congresax talabon), "tinggiri batang" (Scomberomorus commersoni) and "kerapu" (Epinephelus sexfasciatus) were found to be middle fat. Meanwhile, from this study it was found that only three types of fish were considered lean.

Results from this study revealed that fish lipids were not distributed uniformly in every part of the whole fish body (Table 2). This finding is in line with what has been report-

Table 2 Percentage of Total Lipids* in Different Parts of the Fish.

\begin{tabular}{|c|c|c|c|c|c|}
\hline \multirow[t]{2}{*}{ Local Name } & \multirow[t]{2}{*}{ Common Name } & \multirow[t]{2}{*}{ Scientific Name } & \multicolumn{3}{|c|}{ Fish Part } \\
\hline & & & Head & Middle $^{* *}$ & Tail \\
\hline “Duri” & Marine catfishes & Lutianus agentimaculatus & $15.3 \pm 3.5$ & $12.3 \pm 2.1$ & $12.2 \pm 2.2$ \\
\hline "Kintan" & Pseudo rhombus & Arius cumatranus & $21.5 \pm 3.4$ & $13.8 \pm 1.1$ & $14.4 \pm 4.9$ \\
\hline "Jenahak" & Golden snapper & Epinephelus sexfasciatus & $10.9 \pm 3.5$ & $6.3 \pm 2.9$ & $12.1 \pm 2.9$ \\
\hline "Kerisi" & Threadfin breams & Scomberomorus commersoni & $9.1 \pm 2.6$ & $13.7 \pm 4.2$ & $10.5 \pm 3.9$ \\
\hline "Gelama kling" & Drum-croaker-jewfish & Pristipomodes typus & $8.5 \pm 2.2$ & $3.2 \pm 1.2$ & $14.1 \pm 3.1$ \\
\hline "Laban" & Tongue soles & Congresax talabon & $4.8 \pm 3.2$ & $3.2 \pm 0.7$ & $14.1 \pm 1.1$ \\
\hline "Malong" & Pike and conger eels & Rastrelliger kanagurta & $4.7 \pm 1.7$ & $9.1 \pm 0.4$ & $7.8 \pm 2.3$ \\
\hline "Kembong" & Indian mackerels & Psettodes crumei & $6.3 \pm 2.9$ & $13.5 \pm 3.8$ & $4.2 \pm 2.8$ \\
\hline "Tinggiri batang" & Spanish mackerels & Scolidon sorrakowah & $4.9 \pm 2.6$ & $4.8 \pm 1.7$ & $5.6 \pm 2.4$ \\
\hline "Kerapu" & Groupers & Cynoglossus lingua & $4.6 \pm 1.6$ & $6.0 \pm 1.41$ & $7.2 \pm 1.7$ \\
\hline "Kebasi” & Anodontostoma & Aacnthurs nigrosis & $5.6 \pm 1.3$ & $4.9 \pm 1.6$ & $3.7 \pm 0.2$ \\
\hline "Yu 9" & Lizardfishes & Anadontostoma chacunda & $2.6 \pm 0.5$ & $3.8 \pm 0.3$ & $2.7 \pm 0.9$ \\
\hline "Bagi" & Aacnthurs nigrosis & Sciaena dussumieri & $3.1 \pm 0.9$ & $1.5 \pm 0.5$ & $1.5 \pm 1.1$ \\
\hline
\end{tabular}

\footnotetext{
* Values are means of triplicate analyses
}

** Means stomach part 


\section{F. Osman, I. Jaswir, H. Khaza'ai et al.}

ed by Kinsella et al. (1977), showing that the distribution of lipid contents from various parts of fish body, such as head, stomach and tail part was different.

According to Piggot and Tucker (1990), apart from the body parts, the total lipid content in the fish also varies according to seasons, species and geographical variation. In the same species the differences can be observed also due to age variation, sex and maturity.

\subsection{Fatty acid profiles}

Detailed fatty acid compositions of the fin fishes studied are listed in Table 3. The compositions were based on the total fats of fish body from three different parts (i.e. head, middle, and tail). The most abundant of PUFA was C22:6 (DHA) (8.18-23.95\%), while C20:5 (EPA) was also present in important proportion (7.13-19.61\%). n-6 Fatty acids were also present in significant proportion. C18:2 n-6 ranged from $5.47-16.11 \%$, while C20:4 $\mathrm{n}-6$ had a range from0.34$13.41 \%$.

For the case of saturated fatty acids, C16:0, C18:0 and C14:0 were found to be the most predominant ones for all types of fish studied. The same trend was observed by Viswanathannair and Gopakumar (1978) and Belling et al. (1997). Lobb and Chow (2000) have also reported that the most abundant of saturated fatty acids in fish oil is C16:0. Palmitic acid was reported to be abundant since it is a key metabolite in fish and its level is not influenced by the diet (Ackman and Eaton, (1966).

With exceptional of "duri" (Arius cumatranus) and "kerapu" (Epinephelus sexfasciatus), in general, the total PUFA contents were higher (48.57-54.36\%) than the saturated fatty acids (33.02- 47.07\%) and MUFAs were the lowest (6.17-14.99\%) in most of the fish studied. "Duri" (Arius cumatranus) and "kerapu" (Epinephelus sexfasciatus) were found to have a bit higher saturated fatty acid presented by $55.59 \%$ and $49.69 \%$ respectively. The trend of fatty acid of fin fish from seawater is slightly different when compared to the fresh water fish, where the concentrations of MUFA were higher than the saturated and PUFA (Suriah et al., 1995). Other researchers have also shown that freshwater fish have lower contents of PUFAs (Vlieg \& Body, 1988). The differences can be due to the fact that freshwater fishes feed mainly on vegetation and plant materials while marine fishes feed in zooplanktons, which is rich in PUFAs.

According to Piggot and Tucker (1990), the n-3: n-6 ratio is a better index in identifying nutritional value of fish oils of different species. Table 3 also shows the ratio of n-3: $n-6$ in fish studied. It is shown that the ratio of n-3: n-6 fatty acids of various fish in this study varied, ranging from 1.68 - 4.13. Though there is no recommended intake in terms of n-3: $n-6$ ratio, evidence in wild animals and estimated nutrient intake during early human development suggest a diet ratio of 1:1 (Simopoulos, 1989).
Comparisons of EPA, DHA, AA contents, PUFA, saturated acids, and the PUFA/saturated acids ratio of fish studied and those of menhaden oil are given in Table 4. Menhaden oil has been proposed by USFDA (FDA, 1997) as a standard PUFA supplements. Results showed that the concentration of n-3 PUFA for the most of the fish studied ranged between $18.79-36.70 \%$, as compared to that of menhaden oil (21.4\%). Furthermore, the PUFA/saturated acids (SAT) ratio of the fish studied with exceptional of "duri" ranged between $0.66-1.47$ while the standard menhaden oil had 0.58 .

In terms of individual PUFA contents, most of the fin fish analyzed had higher contents of AA and DHA fatty acid than menhaden oil (Table 4). The AA of the fish studied ranged from 0.34 to $13.41 \%$. However, majority of species had a concentration of $1.05-7.16 \%$. Only "duri" (Arius cumatranus) had a lower content of AA (0.34\%) than menhaden oil (0.47\%). AA is a precursor of prostaglandin and thromboxan which influence blood clotting and its attachment to the endothelial tissue during wound healing as well as growth development (Osman, et al., 2001). As for DHA content, all the fish studied had higher percentage of DHA fatty acid, as compared to menhaden oil (7.9\%). The highest level one was found in "bagi" (Aacnthurs nigrosis) (23.95\%) which is three times higher than menhaden oil. However, for the EPA, most of the species studied had lower concentration $(7.51-11.53 \%)$ than the EPA concentration of menhaden oil (12.5\%). This finding was in line with the finding reported by Osman, et al. (2001) and Wang et al. (1990) who reported similar results. The authors revealed that marine fish were rich in n-3 especially EPA and DHA.

\section{CONCLUSIONS}

Seafood-origin proteins and fatty acids play an important role in the human diet. The PUFAs are crucial in terms of human feeding physiology. In the light of literature and the findings, it can be concluded that fin fish found in Pulau Tuba in the Langkawi area, are beneficial for human health as they have considerable amount of PUFAs, especially AA and DHA fatty acids .

\section{ACKNOWLEDGEMENTS}

This study was funded by the Research Centre of the International Islamic University Malaysia. 


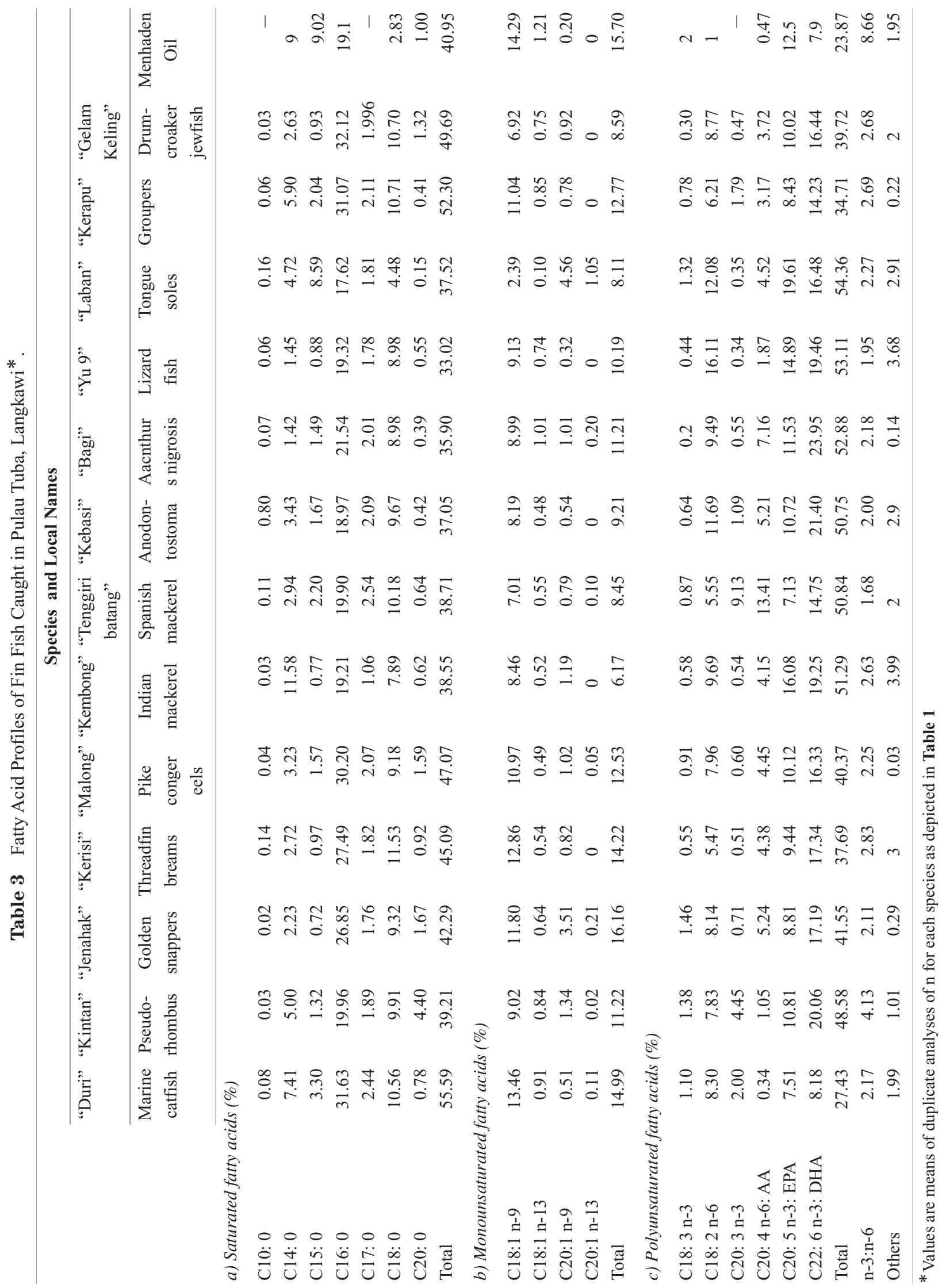


Table 4 Saturated and Unsaturated Fatty Acids Content (\%) of Fin Fish in Pulau Tuba, Langkawi, as Compared to Menhaden oil.

\begin{tabular}{llrrrrrrr}
\hline \multicolumn{1}{c}{ Local Name } & \multicolumn{1}{c}{ Species } & EPA & DHA & AA & $\begin{array}{c}\text { PUFA } \\
\text { n-3 }\end{array}$ & $\begin{array}{c}\text { PUFA } \\
\text { n-6 }\end{array}$ & SAT & PUFA/SAT \\
& & & & & & & \\
\hline & Marine catfish & 7.51 & 8.18 & 0.34 & 18.79 & 8.64 & 55.59 & 0.49 \\
"Duri" & Pseudo rhombus & 10.81 & 20.06 & 1.05 & 36.70 & 8.88 & 39.21 & 1.24 \\
"Kintan" & Golden snappers & 8.81 & 17.19 & 5.24 & 28.17 & 13.38 & 42.29 & 0.98 \\
"Kenahak" & Threadfin breams & 9.44 & 17.34 & 4.38 & 27.84 & 9.85 & 45.09 & 0.84 \\
"Malong" & Pike conger eels & 10.12 & 16.33 & 4.45 & 27.96 & 12.41 & 47.07 & 0.86 \\
"Kembong" & Indian mackerel & 16.08 & 19.25 & 4.15 & 36.45 & 13.84 & 38.55 & 1.33 \\
"Tinggiri batang" & Spanish mackerel & 7.13 & 14.75 & 13.41 & 31.88 & 18.96 & 38.71 & 1.31 \\
"Kebasi" & Anadontostoma & 10.72 & 21.40 & 5.21 & 33.85 & 16.9 & 37.05 & 1.37 \\
"Bagi" & Aacnthurs nigrosis & 11.53 & 23.95 & 7.16 & 36.23 & 16.65 & 35.90 & 1.47 \\
"Yu 9" & Lizard fish & 14.89 & 19.46 & 1.87 & 35.13 & 17.98 & 33.02 & 1.40 \\
"Laban" & Tongue soles & 19.61 & 16.48 & 4.52 & 37.76 & 16.60 & 37.52 & 1.45 \\
"Kerapu" & Groupers & 8.43 & 14.23 & 3.17 & 25.23 & 9.38 & 52.30 & 0.66 \\
"Gelama kling" & Drum-craoker-jewfish & 10.02 & 16.44 & 3.72 & 27.23 & 12.49 & 49.69 & 0.80 \\
& Menhaden oil & $\mathbf{1 2 . 5}$ & $\mathbf{7 . 9}$ & $\mathbf{0 . 4 7}$ & $\mathbf{2 1 . 4}$ & $\mathbf{2 . 4 7}$ & $\mathbf{4 0 . 9 5}$ & $\mathbf{0 . 5 8}$ \\
\hline
\end{tabular}

\section{References}

1. Ackman, R.G. Marine lipids and fatty acids as components of the human diet. Unpublished report (1973).

2. Ackman, R.G.; Eaton, C.A. Some commercial Atlantic herring oils: Fatty acid composition. Journal of Fish Res. 23, 991 (1966).

3. Alasalvar, C.; Tylor, K.D.A.; Zubcov, E.; Shahidi, F.; Alexis, M. Differentiation of cultured and wild sea bass (Dicentrarchus labrax): Total lipid content, fatty acid and trace mineral composition. Food Chemistry. 79 (2), 145-150 (2002).

4. Bang, H.O.; Dyerberg, J.; Hjorne, N. The composition of food consumed by Green Eskimos. Acta. Med. Scand. 192, 85-94 (1976).

5. Belling, G.B.; Abbey, M.; Campbell, J.H.; Campebell, G.R. Lipid content and fatty acid composition of 11 species of Queensland (Australia) fish. Lipids. 32 (2), 621-626 (1997).

6. Bringas-Alvarado, L.; Ortega-García, J.; NavarroGarcía, G.; Pacheco-Aguilar, R. Characterization of the lipid composition and natural antioxidants in the liver oil of Dasyatis brevis and Gymnura marmorata rays. Food chemistry. 87 (1), 89-96 (2004).

7. Çelik, M.; Diler, A.; Küçükgülmez, A. A comparison of the proximate compositions and fatty acid profiles of zander (Sander lucioperca) from two different regions and climatic conditions. Food Chemistry. 92 (4), 637641 (2005).

8. Conner, W.E. The beneficial effects of omega-3 fatty acids: cardiovascular disease and neurodevelopment. Current Opinion in Lipidology. 8, 1-3 (1997).
9. Food and Drug Administration (FDA). Federal registerrules and regulations. Food labeling: requirements for nutrient content claims, health claims, and statements of nutritional support for dietary supplements. 62 (108), 49859-49868 (1997).

10. Folch, J.; Lee, M.; Stanley, G.H. A simple method for the isolation and purification of total lipids from animal tissues. J. Biol. Chem. 226, 497-496 (1957).

11. Haliloğlu, H.I.; Bayir, A.; Sirkecioğlu, A.N.; Aras, N.M.; Atamanalp, M. Comparison of fatty acid composition in some tissues of rainbow trout (Oncorhynchus mykiss) living in seawater and freshwater. Food Chemistry, 86 (1), 55-59 (2004).

12. Jasinghe, J.A.G.; Wimalaseba, S.; Wigesundara, R.C. Fatty acid composition of some Sri Lankan fish and prawns with special reference to Omega-3 fatty acids. ASEAN Food Journal. 11 (1), 35-41 (1996).

13. Jayasinghe, J.A.G.; Mubarak, A.M.; Wimalasena, S.; Wijesundara, R.C. Fatty acid composition of some Sri Lankan fish and prawns with special reference to omega-3 fatty acids. ASEAN Food Journal. 11 (1), 3542 (1996).

14. Justi, K.C.; Hayashi, C.; Visentainer, V.N.; De’Souza, E.; Matsushita, M. Influence of feed supply time on the fatty acid profile of Nile tilapia (Oreochromis niloticus) fed on a diet enriched with n-3 fatty acids. Food chemistry. 80 (4), 489-493 (2003).

15. Kinsella, J.E. Fish and seafoods: Nutritional implication and quality issues. Food Technology. 5, 146-150 (1988).

16. Kinsella, J.E. Effects on polyunsaturated fatty acids on factors related to cardiovascular disease. Am. J. Car- 
diol. 60, 23G (1987).

17. Kinsella, J.E. Food component with potential benefits: the n-3 polyunsaturated fatty acids of fish oils. Food Technology. 40 (2), 89-97 (1986).

18. Kinsella, J.E.; Shimp, J.L.; Mai, J.; Weihrauch, J. Fatty acid content and composition of freshwater fin fish. Journal of American Oil Chemistry Society. 54, 424429 (1977).

19. Leaf, A.; Weber, P.C. Cardiovascular effects of n-3 fatty acids. New Engl. J. Med. 318, 549 (1988).

20. Lobb and Chow Fatty acids in foods and their health implications (2nd edn.). New York. Marcel dekker. inc. (2000).

21. Osman, H.; Suria, A.R.; Law, E.C. Fatty acid composition and cholesterolcontent of selected marine fish in Malaysia waters. Food chemistry. 73 (1), 55-60 (2001).

22. Piggott, G.M.; Tucker, B.W. The effect of Technology on Nutrition. Marcel Dekker. Inc. New York. USA. (1990).

23. Ratkowsky, D.A.; Olley, J.; Jayasinghe, J.A.G.; Wijesundara, R.C. A consistent correlation between monounsaturated and n-3 polyunsaturated fatty acids in flesh of fish caught at different latitudes. ASEAN Food Journal. 11 (1), 43-47 (1996).

24. Saito, H.; Yamashiro, R.; Alasalvar, C.; Konno, T. Influence of diet on fatty acids of three subtropical fish, subfamily caesioninae (caesio diagramma and c.tile) and family siganidae (siganus canaliculatus). Lipid. 34, 1073-1081 (1999).

25. Shahidi, F. Functional seafoods lipids and proteins. in Functional Foods Biochemical \& Processing Aspects. (Mazza, G. ed.). Lancester: Technomic Publishing Company. Inc. pp. 381-401 (1998).
26. Skonberg, D.I.; Perkins, B.L. Nutrient composition of green crab (Carcunus maenus) leg meat and claw meat, Journal of food chemistry. 77, 401-404 (2002).

27. Simopoulos, A.P. New products from the agri-food industry: the return of n-3 fatty acids into the food supply. Lipid. 34, s297-s301 (1999).

28. Simopoulos, Artemis. Omega-3 fatty acids in health and disease and in growth and development. American Journal of Clinical Nutrition. 54, 438-63 (1991).

29. Simopoulos, A.P. The future direction of nutrition research: a nutrition and food science agency is the key to progress. Journal of Nutrition. 199 (1989).

30. Suriah abd. Rahman; Teh Sing Huah; Osman Hassan; Nik mat Daud. Fatty acid compositions of some Malaysian freshwater fish. Journal of food chemistry. 54, 45-49 (1995).

31. Suzuki, H.; Okazaki, K.; Hayakawa, S.; Wada, S.; Tamura. Influence of commercial dietary fatty acids on polyunsaturated fatty acids of cultured freshwater fish and comparison with those of wild fish of wild fish of the same species. J. Agric. Food Chem. 34, 60-62 (1986).

32. Viswanathannair, P.G.; Gopakumar, K. Fatty acid compositions of 15 species of fish from tropical waters. Journal of food science. 43, 1162-1164 (1978).

33. Vlieg, P.; Body, D.B. Lipid contents and fatty acid composition of some New Zealand freshwater finfish and marine finfish, shellfish and roes. Journal of marine freshwater Res. 22, 151 (1988).

34. Wang, Y.J.; Miller, L.A.; Perren, M.; Addis, P.B. Omega3 Fatty acids in lake superior fish. Journal of food science. 55, 71-73 (1990). 